BOGATIKOV Yuri,

Head of the Public Research Interdisciplinary Project "Autism: Today and Tomorrow"

CHERNIKOVA Natali,

pedagogue-analyst, correction center "Balance"

\title{
THE VALUE OF PARENTAL INVOLVEMENT IN THE EDUCATION OF AN AUTISTIC CHILD
}

Abstract. The article considers the issues of participation of parents and other family members in the process of habilitation, development, correction and socialization of a child with autism and other developmental disorders. The importance and necessity of such work is noted. It is emphasized that enhancing the role of parents in raising children with developmental disabilities is considered at the global level as one of the factors improving the current state of such children and improving the forecast for their future. Objective reasons for mandatory inclusion of parents in the process of correction of development of a child with autism are:

- the possibility of constant monitoring of the child, that is, the identification of peculiarities of behavior, the specifics of expression of emotional-volitional manifestations, causal relationship between psychological or sensory stimuli and the reaction of the child to them;

- psychological and emotional connection between the child and parents;

- constant contact with the child.

This enables the gathering of information in order to work with the psychologist and defectologist to build an individual system of work with the child that will be as adequate as possible to its psychophysiological state and implement it.

In the discussed case, parents conducted a multidisciplinary combination of recommendations of psychiatrists, psychologists and defectologists. The comprehensive approach to corrective work is based on the control of the physiological comfort of the child, that is, the satisfaction of all of her physiological needs, and her psychological comfort, such as the absence of frustration factors, as well as factors causing her excitement, anxiety, etc., providing the proper psychophysiological state, conducive to occupations, etc.
As a fundamental factor, it lays the foundation for reducing autistic manifestations in a child; it is considered the creation of a favorable psycho-emotional environment in the place of the child's primary stay, that is, in the room where the kid lives and in the family circle. Maintaining physiological comfort was based on the organization of proper healthy eating and organization of full rest, that is, regulation of sleep. The development of a complex of our reactions to the positive and negative effects of the child has a great importance.

Psycho-pedagogical correction is supplemented by physiologically substantiated physical activity, which is realized through the implementation of a number of physical exercises and the organization of system labor therapy, which consists in the implementation of a variety of domestic and some agricultural operations, with the emphasis on the joint execution of each operation.

The principles of our practical work are based, first of all, on the psychological and educational preparation of parents, both on the formation of their own positive psycho-emotional state, and on the creation of a line of behavior concerning the child.

Using the example of an individual family, it has been demonstrated that the constant, consistent and persistent work of parents on correction and socialization, carried out on the basis of domestic pedagogical methods with some adaptation to the individual characteristics of the child, carried out in collaboration with defectologists and correctional teachers, leads to overcoming a number of developmental disorders and reduce autistic manifestations in a child.

Keywords: development; correction; habilitation; socialization; adaptation; autistic manifestations; psychological comfort; domestic pedagogy.

Одержано редакиією 17.01.2019 Прийнято до публікаиіï 21.01.2019

DOI 10.31651/2524-2660-2019-1-181-185

ORCID 0000-0001-5818-4656

\section{ФУЧиАА Омена Микомаївна,}

кандидат педагогічних наук, доцент, доцент кафедри іноземних мов,

Національний університет " $\Lambda$ ьвівська Політехніка" e-mail: helenfuchila@gmail.com

ORCID 0000-0003-4037-4122

\section{БАМАЦЬКА Аюбов Петрівна,}

старший викладач кафедри іноземних мов,

Національний університет " $\Lambda$ ьвівська Політехніка" e-mail: lubov.balatska@gmail.com

УДК 377.018(493.3/.4)

\section{ОСОБАИВОСТІ ОРГАНІЗАЦІЇ ПРОФЕСІЙНОЇ ОСВІТИ ДОРОСАИХ У ФААНДРІЇ (БЕАЬГІЯ)}

у статті розглянуто деякі аспекти професійної освіти дорослих у фрламаномовній спільноті Бельгії (Фландрії). Проаналізовано структуру неформальної професійної освіти дорослих та діяльність двох основних провайдерів неформального профресійного навчання, Фламандсъкої служби зайнятості та професійної підготовки $і$ Фламандсъкої агениї підприємниитва (ФАП) - Синтра Фландерс. Відмічено переваги та недоліки неформальної профресійної освіти дорослих Фландрії та проблеми залучення громадян до навчання у ній.

Ключові слова: Фландрія (Бельгія); нефрормальна профресійна освіта дорослих; ринок праиі; навчання підприємниитву; підвищення квалірікаuіï.

Постановка проблеми. Розглядаючи різні аспекти професійної освіти доросмих, потрібно зауважити, що в епоху гцобалізації та стрімких змін ринку праці в 
усьому світі саме вона стає ключовою у процесах боротьби із безробіттям та, водночас, розвитку сучасних форм малого i середнього приватного підприємництва. Дослідження ролі професійної освіти та, зокрема, професійної освіти дорослих у розвитку та зменшення безробіття проводять чисменні зарубіжні науковці, зокрема, Д. Аутор, І. Де Мейер, Д. Ештон, М. Гус, В. Kic, А. Манінг, Е. Морен, Д. Розен, Д. Тесмар, українські науковці Н. Мукан, О. Проценко, М. Сорока тощо. Економіка Бельгії характеризується поступовим зростанням кількості приватних підприємств, а також низькою та стабільною кількістю припинень їхньої діяльності, у тому числі з приводу банкротств. Ця тенденція $\epsilon$, на перший погляд, позитивною, але насправді ці дані можуть свідчити про застій, чи дуже слабкий прогрес - один з найнижчих в Свропі. Отже, економіка Бемьгії має дуже низький рівень «креативної деструкції", при якій більш старі і менш адекватні до сучасних умов компанії витісняються із ринку більш молодими та продуктивними, а це, в свою чергу, демонструє неприпустимо низький рівень інновацій на підприємствах. Одним 3 найбільш ефективних шляхів для протидії цій тенденції $\epsilon$ підвищення кваліфікації та курси підприємництва із орієнтацією на інновації [1]. Досвід організації та діяльності такої освіти доросмих у розвинених країнах Свропи, а зокрема, у Фмандрії (Бемьгія) може бути надзвичайно корисним i для розвитку неформальної професійної освіти доросмих в Україні.

Мета статті. Проаналізувати досвід організації професійної освіти дорослих у Фмандрії (Бемьгія) з метою його можиивого використання у сфрері професійної освіти дорослих в Україні.

\section{Виклад основного матеріалу до- сиідження.}

У фмаманомовній спільноті Бельгії професійну освіту дорослих (ПОД), тобто професійну освіту протягом життя забезпечує значна кількість різноманітних організацій. Найважливішими 3 них вважаються центри освіти дорослих, Фмамандська служба зайнятості та професійної підготовки (ФСЗП) (Flemish Service for Employment and Vocational Training), Фмамандське агентство підприємництва (ФАП) - Синтра Фмандерс (Flemish Agency for Entrepreneurship - Syntra
Flanders), центри професійної освіти у галузі сільського господарства та соціокумьтурні організації. Усі вони охопцені системою зовнішнього контролю за якістю наданих поскуг, хоча підпорядковуються різним міністерствам та їхнім підрозділам, оскільки різні види ПОД можуть бути організовані різними компаніями, соціальними партнерами або окремими особами [2].

Отже, Міністерство освіти і навчання керує середньою освітою дорослих, вищою професійною освітою дорослих та художньою освітою часткової зайнятості. Міністерство працевлаштування контроҺює професійну освіту дмя безробітних та працевлаштованих (підвищення кваліфікації), яку надає ФСЗП, а також навчання дия підприємців (Синтра Фландерс та іiі навчальні центри). Міністерство сільського господарства керує відповідним напрямком навчання, а Міністерство культури - соціокультурною діяльністю.

Обидві агенції, ФСЗП та Синтра Фмандерс, працюють безпосередньо під керівництвом Віддіку праці та соціального господарства із соціальними партнерами, представленими у Раді керівників. ФСЗП надає професійну освіту дмя дорослих у своїх кваміфікаційних центрах та у співпраці із партнерами, які беруть участь у курсах дия безробітних. Синтра Фмандерс, натомість, було засновано Відділом праці та соціального господарства дия стимулювання, підтримки та розвитку підприємництва (а саме, малого та середнього бізнесу). Підприємницьке навчання проводиться у навчальних центрах Синтра [3].

У Бельгії існує можливість дия навчання дорослих в умовах формальної та неформальної освіти. ФСЗП та Синтра Фландерс є саме тими організаціями, що надають освіту дорослим поза межами формальної освіти дорослих. Приблизний розподіл кількості дорослих учнів у формальній та неформальній системах освіти дорослих у 2007/2008 н.р. був таким: середня професійна освіта дорослих (формальне навчання) - 134426; програми ФСЗП - 48924; курси підприємництва Синтра - 38049 [4]. Як видно, кількість дорослих у формальній освіті донедавна була більшою, оскільки здійснення певних видів приватного підприємництва вимагало наявність сертифікату державного зразка. Сучасні тенденції цього процесу буде розглянуто нижче. 
Отже, ФСЗП є головним провайдером професійної підготовки у Фмандрії. Це державна скужба, яку контролюють представники працедавців та профспінок (на рівних правах). Ї̈ї основним завданням $\epsilon$ організація навчальних курсів, орієнтованих на ринок праці. Законодавча база ФСЗП спирається на Спеціальний закон про конституційну реформу 1980 р., що підпорядкував професійне навчання вцадним структурам спільнот [5].

ФСЗП організує навчання дия осіб, які шукають роботу, а також для працедавців та працівників. Це або короткі курси для ознайомлення з можливостями ринку праці, або функціонально орієнтовані індивідуалізовані курси. Курси можуть також здійснюватись у співпраці з сторонніми організаціями (наприклад, навчання на робочому місці у компаніях). Випускники ФСЗП отримують особливий сертифікат. Він не відповідає вимогам до дипломів формального сектора освіти, але його наявність позитивно сприймають працедавці. Професійне навчання у ФСЗП та його діяльність у галузі працевцаштування також охоплює окремі програми для груп соціального ризику. Робота ФСЗП в основному фінансується урядом Фмандрії, 3 яким укладено відповідну угоду. Крім того, вона отримує фінансування із Європейського Союза та від працедавців, зацікавлених у проведенні курсів на робочих місцях [6].

ФАП Синтра Фмандерс - це головний фмамандський провайдер навчання менеджменту для підприємців малого та середнього бізнесу. Вона розпочала діяльність у 2006 р. Освіта та навчання, які пропонує Синтра, забезпечують 5 регіональних центрів (кампусів) Синтри. Це - неприбуткові організації, що мають свій вмасний юридичний статус. Крім учнівства та курсів підприємництва, вони також пропонують програми, розробмені для приватних підприємців і старших менеджерів компаній. Цільові групи Синтра Фцандерс - це потенційні приватні підприємці та підприємці, які вже розпочали бізнес. Учасники отримують сертифікат тренінгу приватного підприємця, що містить дані про курси, які вони завершили, які затверджує центральний офіс Синтра Фцандерс [7]. Агенція Синтра Фмандерс одночасно отримує фінансування і надає його. Вона фінансує регіональні центри, які отри- мують операційне та інвестиційне фінансування.

Операційне фінансування включає субсидії на учнівство, субсидії на сертифіковане та несертифіковане навчання та, де можливо, фінансування проектів. Воно охопцює також кошти організації екзаменів та придбання обладнання. Його величина розраховується за кількістю учнів, чиє навчання закінчується екзаменом. Інвестиційне фінансування включає субсидії на оренду приміщень, купівлю та утримання будівель.

Джерело фінансування самої Синтра Фмандерс складається в основному 3 внесків від Фцамандського уряду. Значно менші кошти агенція отримує за рахунок незачного вцасного прибутку (часткова оплата курсів деякими групами учасників) та інших, в основному Європейських, субсидій [6, с.44].

Фмамандська система професійної освіти дорослих має низку позитивних рис, які варто відмітити. Це, зокрема, широкий діапазон опцій професійної освіти на різних рівнях. Базова середня освіта пропонує програми повної та часткової занятості, а професійна освіта упродовж життя забезпечує подальше навчання та можливості "другого шансу" у центрах освіти дорослих, ФСЗП та Синтра Фцандерс. Ії̈ діяльність полегшує факт, що молодь Фцандрії віком 15 років демонструє значні успіхи у читанні, математиці та природничих дисциплінах, що відмічає Програма міжнародного оцінювання учнів, у якій Фцандрія постійно займає очільні місця. Ця програма перевіряє не академічні знання учнів, а уміння ї застосовувати у життєвих ситуаціях, отже готовність молодих

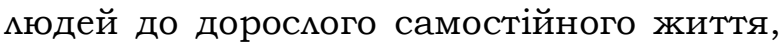
що $\epsilon$ визначною характеристикою успішного професійного розвитку у майбутньому. При цьому отримання загальної повної середньої освіти $\epsilon$ обов'язковим до 18 років, із можливістю освіти 3 частковою зайнятістю від 16 років. Водночас, система професійної підготовки Фцандрії приділяє прискіпливу увагу навчанню підприємницької діяльності за допомогою агенції Синтра Фцандерс, яка пропонує гнучкі шляхи дмя отримання компетенцій, необхідних підприємцям.

У той же час система стикається 3 певною кількістю викликів. По-перше, певна кількість учнів має дуже низький рівень грамотності; учнями в школі 
опікуються до 12 років, після чого їхні можливості подаАьшого розвитку до майбутньої професії $є$ доволі обмеженими. Як наслідок, спостерігається значний відсоток учнів, що не закінчують середню освіту. У 2006 р. 12,4\% 18-24-річних молодих мюдей не мали сертифікату про середню освіту, частина з них навіть не починала навчання у середній школі, і ці показники знижуються дуже повільно, оскільки їхні причини, не зникають.

Деякі ділянки професійної освіти не повною мірою використовують можливості навчання на робочому місці, та його якість та результативність також $€$ різною. Набір пропозицій визначається в основному потребами учнів у професійній освіті на базі середньої шкільної освіти, а механізми, що брали би до уваги потреби ринку праці, є обмеженими. Якість кар'єрного консультування, що здійснюється у обов'язковій освіті, вкАючаючи співробітництво між школами та центрами допомоги учням, не систематизована, а джерела кар'єрної інформації фрагментовані [5, с.15].

Висновки $i$ перспективи подальших досліджень. Аналізуючи різні аспекти діяльності організацій ФСЗП та ФОП Синтра Фмандерс, що здійснюють професійну освіту дорослих та навчання підприємництву у фмаманомовній спільноті Бельгії, автори стверджують, що професійна освіта дорослих $\epsilon$ невід'ємною складовою економіки країни: вона впливає на формування ринку праці та розподіл матеріальних цінностей, на покращення соціального статусу та конкурентоспроможності громадян на сучасному ринку праці (як у своїй країні, так і за кордоном), як наслідок - зменшення рівня маргіналізації суспільства. Подальше вивчення та глибокий аналіз інструментів професійного навчання дорослих у розвинених країнах Європи та світу дозволить успішно розвинути його і в Україні, використовуючи його переваги та уникаючи недоміків.

\section{Список бібціографічних посимань}

1. Flemish agency for entrepreneurial training - Syntra Flanders. URL: https://ec.europa.eu/esf/transnationality/syntraflanders-1358

2. Mukan N., Fuchyla O. Functional literacy learning in the system of adult education in Belgium. Advanced education. Kyiv, 2016. № 6. C.34-39.

3. EQAVET Report of Belgium (Flanders). Dublin, Ireland: European Quality Assurance for VET, EQAVET Secretariat, 2016. 7 p.

4. Flemish Ministry of Education and Training. "Background report", Learning for Jobs: The OECD Policy Review of Vocational Education and Training, FMET, Brussels, 2009. 221 p.

5. Kis V. Learning for jobs: OECD reviews of vocational education and training - Belgium (Flanders). Paris, France: OECD, 2010. 76 p.

6. National report on the Development and State of Art of Adult Learning and Education (ALE). The 6th International Conference on Adult Education (CONFINTEA VI), 9 June 2008. Flemish Community of Belgium, Ministry for Education and Training. Hamburg, Germany: UNESCO UIL, 2008. 126 p.

7. Rosen D. J., De Meyer I. Case Study: Belgium (Flemish Community): Teaching, Learning and Assessment for Adults: Improving Foundation Skills. Paris: OECD Publishing, 2008. 31 p.

\section{References}

1. Flemish agency for entrepreneurial training - Syntra Flanders. Retrieved from https://ec.europa.eu/esf/transnationality/syntraflanders-1358

2. Mukan, N., Fuchyla, O. (2016). Functional literacy learning in the system of adult education in Belgium, Advanced education, 6, 34-39.

3. EQAVET Report of Belgium (Flanders) (2016). European Quality Assurance for VET, EQAVET Secretariat, Dublin, Ireland.

4. Flemish Ministry of Education and Training (2009a). "Background report", Learning for Jobs: The OECD Policy Review of Vocational Education and Training. Brussels: FMET.

5. Kis, V. Learning for jobs: OECD reviews of vocational education and training (2010). Belgium (Flanders). Paris, France: OECD.

6. National report on the Development and State of Art of Adult Learning and Education (ALE). (2008). The 6th International Conference on Adult Education (CONFINTEA VI), 9 June 2008. Flemish Community of Belgium, Ministry for Education and Training. Hamburg, Germany: UNESCO UIL.

7. Rosen, D. J., De Meyer, I. (2008). Case Study: Belgium (Flemish Community): Teaching, Learning and Assessment for Adults: Improving Foundation Skills. Paris: OECD Publishing.

\section{FUCHYLA Olena,}

$\mathrm{PhD}$ in Pedagogic, Associate Professor of the Department of Foreign Languages

\section{BALATSKA Liubov}

Senior lecturer of the Department of Foreign Languages Lviv Polytechnic National University

e-mail: helenfuchila@gmail.com

\section{SOME FEATURES OF VOCATIONAL ADULT EDUCATION IN FLANDERS (BELGIUM)}

Abstract. Introduction. Analyzing the vocational education of adults in Flanders (Belgium), the authors can conclude that it greatly influences the whole economy of the country. The number of private enterprises in Flanders grows steadily, but the progress of economy is rather slow, because of the lack of innovations in the small and medium business. Therefore, older and out-of-date enter- prises are not replaced by younger ones using the innovative tools and technologies. One of the most effective ways of improving the tendency is vocational education including on-the-job training, as well as entrepreneurial training for small and medium businesses provided for job seekers and employees, managers and adults launching their first 
business projects with the aim of introducing them successfully to the labour market.

The purpose of the article is to analyze the experience of organizing the vocational education and training (VET) of adults basing on the example of two main VET providers of Flanders (Belgium) for its eventual application in the sphere of adult vocational education in Ukraine.

The methods of analysis, synthesis and comparison are used in the article.

Results. The examples of organizing vocational education and training for adults in Flanders (Belgium) show the ways of improving labour market competitiveness of adults while they are seeking for a job, or want to acquire some new skills necessary for their future careers, or even going to launch their own business. One of them, Flemish Employment and Vocational Training Agency, provides vocational training courses for job seekers and employees in their own training centers or cooperating with companies which organize on-the-job training. Flemish Agency for Entrepreneurship - Syntra Flanders organizes the entrepreneurial courses for adults taking into account modern tendencies of labour market and technical innovations. Both institutions are financed mainly by the Flemish government. Provided education and training undergoes some challenges and has its opportunities originated in the Flemish economy. Therefore, the investigated expe- rience of two non-formal representatives of Belgian VET providers can be extremely useful for the development of similar programs in Ukraine.

Originality. This research has been done for the first time with the use of original literature sources.

Conclusion. Having analyzed different aspects of educational activities of non-formal institutions in Flanders (Belgium), the authors can conclude that non-formal adult education can be the tool for achieving several aims of state significance: improving the competitiveness of the citizens on the modern labour market in their own country and abroad lowering the level of unemployment and criminalization of the society, as well as stimulating the improvement of economic level in particular and the status of the country in general. Further investigations and careful analysis of tools and programs for non-formal adult education in the developed countries of European Union will promote developing it in Ukraine.

Key words: Flanders (Belgium); non-formal vocational adult education; labour market; entrepreneurial training; professional development.

Одержано редакиією 21.01.2019 Прийнято до публікаиї̈ 28.01.2019

DOI 10.31651/2524-2660-2019-1-185-192

ORCID 0000-0003-0469-4743

\section{FILATOWA Lada}

Kandydat Nauk, Profesor nadzwyczajny

katedra początkowej, przedszkolnej i profesjonalnej edukacji

Charkowski Narodowy Uniwersytet Pedagogiczny im. Grzegorza Skoworody lada.avia@gmail.com

УДК 378.091.2:17.022.1

\section{BADANIE TYPOLOGII WIZERUNKU (IMIDŻU): DOŚWIADCZENIE, REALIA, PERSPEKTYWY}

Artykut podejmuje aktualna na dzień dzisiejszy problematyke: budowanie pozytywnego wizerunku, jako elementu osobistego, czy też zawodowego. Rozbudowa w Ukrainie całościowego systemu $i$ ukierunkowanie państwa na demokratyczne zasady $w$ oświacie, biznesie, chęci młodego pokolenia być konkurencyjnym na rynku pracy - motywuje do wyuczenia światowego doświadczenia $w$ kierunku budowania wizerunku, wypracowania wlasnych teoretycznych $i$ praktycznych nowinek. Dlatego właśnie ukazana problematyka jest aktualna, a artykut na czasie.

Kluczowe stowa : wizerunek (imidz); ksztaltowanie imidż; imagelogia; typologia wizerunku (imidżu); socjalne role.

Określenie problematyki. Wielość społecznych ról człowieka, pozwala przypuszczać także różnorodność postaw wizerunków, czy też własnych styli. Jednak badania prowadzone $\mathrm{w}$ tym zakresie pozwalaja jedynie na jednostronne określenie własnego stylu: $z$ perspektywy profesjonalnej działalności, lub jako odniesienie do pozycji zajmowanej w środowisku społecznym (lider, kierownik, podległy, koordynator projektu, a także in.). Współczesne potrzeby wymagaja różnostronnego określenia niniejszej problematyki, co motywuje w następstwie rozszerzenie naukowych badań.

Problematyka studiów nad typologia stylu własnego, w Ukrainie otrzymała nowe ukierunkowania i aktualność w ostatnim dziesięcioleciu. Ma to ścisły związek $z$ potrzeba wytworzenia pozytywnego wizerunku profesjonalnych ukierunkowań: robotników, pracowników różnorakich służb, kierownictwa i in.

Analiza ostatnich badań i publikacji. Zagraniczni uczeni uwagę do koncepcji wizerunku ukształtowali $\mathrm{w}$ połowie XX wieku. Większość specjalistów w tym zakresie, jako założyciela teorii wizerunku uważa K. Bouldinga, który w latach 60tych minionego stulecia wprowadził termin „,imidż - wizerunek”, mając na uwadze uniwersalny mechanizm, który bierze udział w rządzeniu socjalnymi procesami na równi pojęcia „wrażenie”. Rozwój imidżologii został związany $z$ praca zagranicznych badaczy (E. Barnou, P. Berd, D. Brustin, K. Mełder i in.), którzy określili podejścia do badań nad teoria wizerunku. Odrębnie został określony 